\title{
Os bebês entre eles: afinal, há interação?
}

\author{
Anna Paula Rolim de Lima
}

\begin{abstract}
* Mestranda da Faculdade de Educação da Unicamp e professora de Educação Infantil na Rede Municipal de Campinas, SP, Brasil. annapaularolim@yahoo. com.br
\end{abstract}

STAMBAK, Mira et al. Os bebês entre eles: descobrir, brincar, inventar juntos. Tradução do espanhol: Suely Amaral Mello; Maria Carmem Silveira Barbosa. Revisão técnica: Ana Lúcia Goulart de Faria. Campinas: Autores Associados, 2011. 196 p.

A leitura de Os bebês entre eles traz à lembrança Rugrats - Os Anjinhos, série americana de desenho animado que estrelou na TV brasileira e marcou minha infância. Nela um grupo de bebês vivencia inusitadas aventuras que só se tornam possíveis porque eles têm a capacidade de se comunicar entre si, numa linguagem incompreensível para os adultos. Os bebês, no entanto, compreendem grande parte do que os adultos falam, mesmo que confundam algumas palavras ou conceitos, o que, na maior parte das vezes, é o elemento propulsor de seus planos de ação, suas explorações, suas peripécias.
O livro remete ao seriado, pois investiga as interações sociais entre bebês e demonstra que a troca entre coetâneos lhes permite construir "momentos comunicativos" personalizados; adaptar o próprio comportamento e a linguagem à dos parceiros da mesma idade; e alcançar soluções inteligentes para os conflitos encontrados.

No desenho, o foco recai sobre as interações sociais dos bebês e suas consequências; sobre sua capacidade coletiva de planejar e encontrar soluções para transpor os mais difíceis obstáculos. E é exatamente isso que compõe o objetivo central de Os bebês entre eles: descobrir, brincar, inventar juntos.

Pode parecer cômico ou ultrajante associar um árduo trabalho de pesquisa científica a um "simples desenho animado", o que torna ainda mais interessante a discussão; ou seja, ao se afirmar que o trabalho das autoras limita-se ao irreal, opta-se pelo argu- 
mento de que é simplesmente impossível que crianças tão pequenas sejam capazes de se comunicar com seus pares. O fato é que, no livro em questão, é demonstrado o desenvolvimento dessas e de outras potencialidades em "simples bebês".

Escrito originalmente em francês e publicado em 1983, Os bebês entre eles: descobrir, brincar, inventar juntos representa um avanço significativo no que se refere à psicologia do desenvolvimento, pois se contrapõe ao egocentrismo piagetiano e desvenda as inúmeras possibilidades de interação desenvolvidas pelos bebês, ressaltando que as interações entre eles não se resumem simplesmente à imitação, mas constituem numerosas e variadas trocas infantis, pautadas tanto na cognição quanto na emoção.

O próprio título do livro, recentemente lançado no Brasil, é bastante sugestivo, principalmente no que se refere à psicologia do desenvolvimento, pois desconstrói a imagem de seres incompletos e incapazes, tradicionalmente atribuída a crianças menores de 24 meses. Além disso, os termos descobrir e juntos convidam o leitor a desvendar o universo coletivo dos bebês.

A metodologia constitui ponto de destaque, com a elaboração das ditas "situações preparadas". O que chama atenção, pois, apesar de criticarem os tradicionais experimentos laboratoriais, comuns às investigações psicológicas, as autoras simulam situações próximas àquelas vivenciadas pelas crianças na creche, delimitando fisicamente seu campo de atuação; o número de crianças envolvidas, que são previamente selecionadas; e os materiais analisados.

A forma de organização do livro é outro elemento atraente, pois, a cada capítulo, é apresentada a descrição de uma "situação preparada", seguida de sua análise. Torna-se interessante aos estudiosos da pequena infância acompanhar, passo a passo, a elaboração desses "experimentos naturais" e seu desenvolvimento.

O primeiro dos cinco capítulos que constituem o livro analisa "as trocas infantis em uma situação de brincadeira motora". 0 objetivo é estimular, entre os bebês, situações de troca que envolvam todo o corpo e não foquem apenas o desenvolvimento cognitivo. Algumas brincadeiras vivenciadas pelas crianças são narradas e, inclusive, contam com ilustrações, como o esconde-esconde, o atirar-se aos colchões e o sapatear. É contagiante acompanhar seu desenrolar, seja pelas análises realizadas ou pelas descrições apresentadas, que tornam visível a comunicação entre os bebês. 
Os olhares, as mímicas, as atitudes e as posturas corporais, as vocalizações e a maneira de se deslocar estão carregadas de significado. Alegrias e satisfações, às vezes decepções, mas também sugestões, aprovações, aceitações, rejeições etc. são claramente percebidas (p. 39).

O segundo capítulo investiga as "trocas infantis em uma situação de exploração de objetos"; para tanto, as crianças são induzidas a manipular pequenos objetos e a realizar diferentes ações com o material. A leitura desta seção permite identificar a criatividade e a capacidade de abstração inerentes ao ser humano, já em idade tão precoce. Parece sugerir, ainda, que os processos cognitivos e afetivos caminham de maneira indissociável.

Uma questão polêmica é abordada no terceiro capítulo, “Trocas infantis em uma situação de brincadeiras de faz-de-conta”. Afinal, crianças menores de três anos transcendem ou não seu contexto imediato?

Particularmente nesta seção é apresentada ao leitor uma série de questões que se configuram em insinuações provocantes e, ao mesmo tempo, apontam elementos que conduzem à construção coletiva de brincadeiras de faz de conta entre bebês de 18 a 26 meses.
Ora, não se negam aqui as dificuldades características da organização dos bebês nas brincadeiras simbólicas; contudo, salienta-se que, apesar disso, os bebês parecem sentir maior prazer em suas realizações e, concomitantemente, ampliam sua consciência em relação ao significado das ações realizadas.

O capítulo quatro, "Brincadeiras motoras entre crianças de 12 a 18 meses", configura a solução encontrada pelo grupo de pesquisa para os questionamentos apresentados pelas educadoras da creche, que criticavam as "situações preparadas", por estarem muito distantes das práticas diárias vivenciadas nas escolas reais, uma vez que o número de crianças por turma era muito superior ao número de crianças que compunham as análises realizadas - no mínimo três e no máximo cinco.

A alternativa seria realizá-las em uma sala real. Foi escolhida, então, uma turma de 12 a 18 meses "que contava apenas com oito crianças" (p. 133). Particularmente, pergunto-me: ainda assim não está distante da realidade, uma vez que a própria autora ressalta o termo apenas?..

A mesma situação que caracteriza o capítulo 1 foi aplicada à referida turma, e foi perceptível seu desenvolvimento intelectual, mediante operações de classificação, seriação e correspondência termo a termo. 
A última sessão investiga "Momentos de conflitos"; contudo, o foco está nas interações infantis e não na individualidade das crianças. Assim, os confrontos representam "momentos construtivos em que as crianças enfrentam ativamente as contradições; momentos organizativos; situações que provocam a necessidade de encontrar estratégias para resolvê-las" (p. 181).

Os bebês entre eles: descobrir, brincar, inventar juntos configura uma fonte rica e de extrema importância para os pesquisadores da pequena infância, pois critica muitos dos comportamentos equivocadamente atribuídos às crianças.

A qualidade do livro é decorrente de vários aspectos: metodologia clara, não intervencionista; densidade das análises de dados; riqueza de detalhes que comprovam a indissociabilidade dos processos cognitivos e afetivos nos momentos de interação, além do olhar atento aos "dizeres e aos fazeres" das crianças.

O livro proporciona uma leitura prazerosa, que prende o leitor e o faz ressignificar o conceito de infância. Merece destaque o estudo da construção do pensamento simbólico, por meio do qual a criança é capaz de demons- trar seus conhecimentos sobre os fatos que constituem seu dia a dia, desvinculando-os de seu contexto real.

Sem dúvida, o aspecto primordial é a comprovação da existência de vida social rica e variada entre crianças tão pequenas, sua autonomia e capacidade de tomar iniciativas, seu anseio por compreender as coisas e as pessoas, sem a necessidade da intervenção direta do adulto. Por fim, o livro nos ajuda "a estarmos atentos para que não se extinga a incansável curiosidade infantil”. 